\title{
Penampilan Hasil Gabah dan Karakter Agronomi Padi Hibrida di Bantul, Yogyakarta
}

\author{
Bambang Sutaryo a, dan Cicilia Tri Kusumastuti ${ }^{\text {b }}$ \\ ${ }^{a}$ Balai Pengkajian Teknologi Pertanian Yogyakarta, DIY, Indonesia, email: b_sutaryo@yahoo.com \\ ${ }^{b}$ Fakultas Pertanian, Universitas PGRI Yogyakarta,DIY, Indonesia,email: astyabady@yahoo.com
}

\section{Article Info}

Article history:

Received 1 Oktober 2018

Received in revised form 11 Oktober 2018

Accepted 15 Oktober 2018

DOI:

https://doi.org/10.32938/sc.v3i04.464

Keywords:

Hipa, Ciherang, IR64

\section{Abstrak}

Penelitian tentang penampilan hasil gabah dan karakter agronomi padi hibrida pada lahan sawah berpengairan teknis, di Bantul, Yogyakarta untuk lima varietas padi hibrida yaitu Hipa 8, Hipa 9, Hipa Jatim 2, Hipa 18 dan Hipa 19 dilaksanakan di Sonopakis, Bantul, Yogyakarta selama musim kemarau (MK) 2015. Bibit berumur 15 hari dengan satu bibit per lubang ditanam secara jajar legowo (tajarwo) $4 \cdot 1$, jarak tanam $25 \times 12,5 \times 50 \mathrm{~cm}$, dengan 256.000 populasi tanaman. Luas plot per varietas adalah $2000 \mathrm{~m} 2$. Varietas tersebut digunakan sebagai perlakuan. Ciherang dan IR64 sebagai varietas populer yang ditanam dengan populasi yang sama oleh petani digunakan sebaga pembanding. Data dianalisis dengan uji t. Hipa 8 dan Hipa 19 memberikan hasil tertinggi (7,9 dan 7,5 t/ha) dibandingkan dengan varietas pembanding maupun varietas yang diuji lainnya. Hasil tertinggi pada Hipa 8 dan Hipa 9 tersebut didukung oleh komponen hasil utama yaitu jumlah gabah isi, jumlah gabah total, dan jumlah anakan produktif. Semua varietas yang dikaji berumur genjah sampai sedang, kecuali Hipa 9 dan Hipa Jatim 2 dengan umur tanaman masing-masing 120 dan 123 hari.

\section{Pendahuluan}

Untuk merealisasikan swasembada pangan yang mencakup padi jagung dan kedelai dalam dua hingga tiga tahun mendatang, pemerintah memprioritaskan empat hal yaitu bibit unggul, pupuk, waktu tanam yang tepat dan perbaikan fasilitas pengairan. Mengingat sejak lima tahun terakhir 20092013 kondisi peningkatan produksi dan pemenuhan kebutuhan pangan tiap-tiap komoditas berbeda, maka pemerintah menargetkan swasembada padi pada tahun 2015 sebanyak 73 juta ton (Satoto $d k k$. 2010).

Produksi padi tertinggi di Indonesia dalam kurun waktu lima tahun terakhir (2009-2013), terjadi pada tahun 2013 yaitu 71,28 juta ton. Dibandingkan dengan tahun sebelumnya, pada 2012 produksi padi sebesar 69,06 juta ton dan pada tahun 2010 sebesar 65,98 juta ton. Laju peningkatan produksi padi tidak hanya didasarkan atas pertimbangan bibit unggul, pupuk, waktu tanam yang tepat, serta pembangunan fasilitas pengairan saja akan tetapi juga ditentukan oleh interaksi antara luasan areal tanam dan produktivitasnya (Anonim, 2014).

Produksi padi di Yogyakarta pada tahun 2012 sebesar 893.620 ton dan ditargetkan menjadi 922.131 ton pada tahun 2014 (Dinas Pertanian DIY, 2012) Salah satu upaya yang dilakukan untuk pencapaian tersebut adalah melalui peningkatan peran inovasi teknologi varietas unggul padi hibrida dan pelaksanaan budidaya secara pengelolaan tanaman terpadu (PTT) (Pikukuh $d k k$. 2008).

PTT merupakan suatu pendekatan yang mempertimbangkan keserasian dan sinergisme antara komponen teknologi produksi (budidaya) dengan sumberdaya lingkungan setempat (Badan Litbang Pertanian, 2007). Dengan demikian, paket teknologi yang disiapkan bersifat spesifik lokasi, yang dapa menghasilkan sinergisme dan efisiensi tinggi, sebagai wahana pengelolaan tanaman dan sumberdaya spesifik lokasi (Hasanudin, 2004). Salah satu komponen PTT adalah penggunaan padi varietas unggul baru (VUB) padi hibrida (Satoto $d k k .2010$ ).

Salah satu VUB padi yang memiliki cita rasa nasi pulen dan produksinya lebih tinggi daripada IR64 adalah Mekongga (Sembiring, 2008). Walaupun pada beberapa tahun terakhir ini, Indonesia mengalami pelandaian laju peningkatan produksi padi sawah sebagai akibat alih fungsi lahan pertanian ke non pertanian, namun peluang peningkatan produktivitas dan produksi padi masih terbuka lebar, antara lain melalui penerapan inovasi teknologi varietas unggul baru padi inbrida dan hibrida dengan produktivitas tinggi (Badan Litbang Pertanian, 2007).

Penanaman padi Indonesia memiliki potensi sekitar 11,5 juta hektar, 10 juta hektar di antaranya lahan sawah berpengairan teknis (Darsana, 2002). Lua penanaman padi di Yogyakarta sekitar 155.457 hektar, yang terdiri atas 112.083 hektar lahan sawah dan 43.364 hektar lahan tadah hujan (Dinas Pertanian DIY, 2012). Sedangkan, data sebaran varietas padi produk Badan Litbang Pertanian di Yogyakarta sampai dengan tahun 2012 menunjukkan bahwa varietas Ciherang, IR64, Situ Bagendit, Membramo, Pepe, Cisadane dan varietas lokal lainnya masih digunakan petani (Dinas Pertanian DIY, 2012). Selain hal tersebut, para petani belum menggunakan teknologi dasar PTT seperti pemberian bahan organik melalui pengembalian jerami ke sawah, pengaturan populasi tanaman secara optimum dengan tanaman jajar legowo (tajarwo), pemupukan berdasarkan kebutuhan tanaman dan status hara tanah, dan pengendalian organisme pengganggu tanaman dengan pendekatan pengendalian hama terpadu.

Sehubungan dengan hal tersebut di atas, maka penelitian tentang keragaan varietas unggul padi hibrida dengan pengelolaan tanaman terpadu perlu dilakukan dengan tujuan untuk mengkaji keragaan varietas unggul padi hibrida melalui PTT dalam upaya memantapkan ketahanan pangan dengan meningkatkan produktivitas beras di Provinsi Yogyakarta.

\section{Metode}

Kajian keragaan hasil dan karakter agronomi varietas unggul padi hibrida melalui pengelolaan tanaman terpadu telah dilakukan di Sonopakis, Kasihan, Bantul, Yogyakarta selama musim kemarau (MK) 2015. Pengkajian menggunakan varietas unggul baru hibrida padi (Hipa) : Hipa 8, Hipa 9, Hipa Jatim 2, Hipa 18 dan Hipa 19. Varietas yang sudah dibudidayakan petani setempat yaitu Ciherang dan IR64 digunakan sebagai pembanding. Lima varietas unggul baru tersebut ditanam masing-masing dengan luas $2000 \mathrm{~m}^{2}$

Variabel-variabel yang diamati adalah (1) Hasil gabah kering panen pe petak ditimbang secara ubinan $(2,5 \mathrm{~m}$ x 2,5 m) sebanyak 10 sampel per petak, kemudian dikonversikan ke hektar; (2). Umur tanaman dihitung dari sebar benih sampai gabah masak panen. (3) Data pertumbuhan dan komponen hasil diambil berdasarkan rata-rata 10 tanaman contoh tiap petak ubinan, meliputi; (a) Tinggi tanaman; (b) Jumlah anakan per rumpun; (c) Jumlah gabah isi per malai, (d) Jumlah gabah hampa per malai, dan (e) Jumlah gabah total per malai. Selain variabel tersebut juga diamati ketahanan terhadap hama-penyakit yang ada selama pertumbuhan tanaman yang diamati secara visual berdasar penilaian skoring Standard Evaluation System for Rice (SES) (IRRI, 1996)

Seluruh hasil pengamatan dianalisis untuk menguji hipotesis rata-rata populasi tiap VUB terhadap varietas pembanding terbaik, dengan $\alpha=5 \%,\left(\mathrm{H}_{0}: \mu_{1}\right.$ $\mu_{2}, \mu_{3} \ldots \ldots \mu_{n}=\mu_{n+1}$ lawanH $_{1}: \mu_{1}, \mu_{2}, \mu_{3} \ldots \ldots . . \mu_{n} \neq \mu_{n+1} ; H_{0}$ ditolak jika $t_{\text {hitung }}>$ $t_{\text {tabel }}$ ), dengan $\mu_{1}, \mu_{2}, \mu_{3} \ldots \ldots . . \mu_{n}$ dan $\mu_{n+1}$ masing-masing adalah rata-rata hasil gabah dan komponen hasil untuk pengamatan tiap varietas dan varietas pembanding terbaik (Gomez dan Gomez, 1995).

\section{Hasil dan Pembahasan}

Salah satu komponen teknologi penting yang memiliki kontribusi besar dalam meningkatkan produktivitas dan pendapatan usahatani padi adalah varietas unggul. Selain hal tersebut komponen pengelolaan dan pemeliharaan budidaya tanaman yang baik juga merupakan komponen penting dalam meningkatkan pertumbuhan dan perkembangan tanaman menjadi lebih baik sehingga dapat dipanen sesuai dengan yang diharapkan. Komponen teknologi tersebut sangat berperan dalam mengubah sistem usahatani padi dari subsistem menjadi usahatani padi yang komersial. Di samping itu kondisi lahan yang digunakan untuk kegiatan kajian ini merupakan salah satu sentra produksi padi sawah berpengairan teknis di Sonopakis, Kasihan, Bantul sehingga diharapkan dapat mendukung keberhasilan pengkajian ini.

\subsection{Pertumbuhan Tanaman}

\section{a. Tinggi Tanaman}

Pada Tabel 1. dapat dilihat bahwa tinggi tanaman varietas bervariasi mulai dari $102 \mathrm{~cm}$ (Hipa 9), hingga $122 \mathrm{~cm}$ (Hipa Jatim 2). Dengan demikian Hipa Jatim2 merupakan varietas padi hibrida dengan tinggi tanaman paling tinggi. Dalam deskripsi varietas unggul baru padi (VUB), Hipa Jatim 2 juga memiliki tinggi sekitar $120 \mathrm{~cm}$ (Badan Litbang Pertanian, 2013). Tanaman dengan ketinggian yang relatif tidak tinggi dapat terhindar dari kerebahan yang disebabkan oleh angin kencang. Tanaman yang rebah dapat menurunkan hasil gabah (Sutaryo \& Sudaryono, 2012)

Tabel 1. Rata-Rata Tinggi Tanaman, Jumlah Anakan Produktif per Rumpun, dan Umur Tanaman Varietas Padi Hibrida, di Sonopakis, Kasihan, Bantul, Yogyakarta, MK2015.

\begin{tabular}{lccc}
\hline $\begin{array}{c}\text { Varietas Padi } \\
\text { Hibrida / } \\
\text { Pembanding }\end{array}$ & $\begin{array}{c}\text { Tinggi } \\
\text { Tanaman (cm) }\end{array}$ & $\begin{array}{c}\text { Jumlah } \\
\text { Anakan (batang) }\end{array}$ & $\begin{array}{c}\text { Umur } \\
\text { Tanaman } \\
\text { (hari) }\end{array}$ \\
\hline Hipa 8 & $121,0^{*}$ & $22,0^{*}$ & $116^{\mathrm{ns}}$ \\
Hipa 9 & $102,0^{*}$ & $14,0^{\mathrm{ns}}$ & $120^{*}$ \\
Hipa Jatim 2 & $122,0^{*}$ & $20,0^{*}$ & $123^{*}$ \\
Hipa 18 & $111,0^{\mathrm{ns}}$ & $18,0^{\mathrm{ns}}$ & $112^{\mathrm{ns}}$ \\
Hipa 19 & $114,0^{\mathrm{ns}}$ & $21,0^{*}$ & $115^{\mathrm{ns}}$ \\
Ciherang & 114,0 & 16,0 & 114 \\
IR64 & 108,0 & 15,0 & 116 \\
\hline
\end{tabular}

Keterangan: * dan ns masing-masing adalah beda nyata dan tidak beda nyata terhadap Ciherang sebagai varietas pembanding terbaik pada uji $\mathrm{t}$ pada tingkat $5 \%$. 
b. Jumlah Anakan Produktif

Jumlah anakan produktif antar varietas padi beragam. Varietas yang memiliki jumlah anakan terbanyak ternyata Hipa 8 (22 batang), sedangkan yang paling sedikit anakannya adalah Hipa 9 (14 batang) (Tabel 1.). Secara umum, jumlah anakan yang diperoleh oleh kelima varietas unggul padi hibrida tersebut tergolong cukup tinggi. Hal ini disebabkan oleh penanaman bibit yang sudah mengikuti pola pengelolaan tanaman terpadu, yaitu penanaman dengan jumlah bibit 1-2 batang per lubang. Dilaporkan, bahwa makin banyak jumlah bibit yang ditanam per lubangnya, semakin sedikit jumlah anakan produktifnya (Simarmata, 2006). Hasil penelitian lapang di Cimalaka, Sumedang, Jawa Barat, bahwa padi yang ditanam dengan 3-5 bibit per lubang, tanaman hanya menghasilkan anakan sekitar 20 anakan per lubang, dengan 2 bibit per lubang menghasilkan anakan sekitar 25 anakan per lubang, dan yang ditanam 1 bibit per lubang mampu menghasilkan sekitar 30 anakan per lubang (Simarmata, 2006). Diindikasikan bahwa makin banyak jumlah bibit akan menyebabkan terjadinya persaingan di antara bibit tanaman padi untuk memperoleh nutrisi dan faktor tumbuh lainnya.

c. Umur Tanaman

Pada Tabel 3. dapat dilihat bahwa umur tanaman paling genjah adalah Hipa 18 (112 hari) dan diikuti oleh Ciherang (114 hari), Hipa 19 (115 hari), Hipa 8 (116 hari), IR64 (116 hari) dan Hipa Jatim 2 (123 hari) yang semuanya dikelompokkan ke dalam umur sedang (>110-125 hari) (Suprihatno $d k k$. 2009). Dari kelima Hipa tersebut, Hipa 18 berumur lebih cepat (112 hari), sedangkan Hipa Jatim 2 berumur paling lama (123 hari). Keadaan tersebut sesuai dengan deskripsi (Badan Litbang Pertanian, 2013). Pada kenyataannya petani lebih menyukai tanaman padi yang berumur genjah sampai sedang, karena kondisi tanaman tetap bagus, tidak roboh, tidak terserang hama burung, dan yang lainnya (BPTP Yogyakarta, 2011)

\subsection{Ketahanan Terhadap Hama dan Penyakit}

Pada Tabel 2. dapat dilihat, bahwa Hipa 8 berdasarkan pengamatan di lapang menunjukkan ketahanan terhadap BLB, sedangkan Hipa 9, Hipa Jatim 2, Hipa 18, Hipa 19 dan IR64 agak tahan terhadap BLB. Ciherang ternyata peka terhadap BLB. Penyakit BLB ini muncul menjelang tanaman akan berbunga. Terserangnya tanaman oleh penyakit BLB ini diduga karena kondisi lingkungan mikroklimat yang agak lembab pada saat akhir fase vegetatif. Namun karena masing-masing varietas Hipa, Ciherang dan IR64 memiliki karakter ketahanan yang berbeda, maka tingkat serangan yang terjadi juga beragam (Sudir \& Suparyono, 2000). Infeksi alam di lapangan lebih parah pada musim hujan dibandingkan dengan yang ada pada musim kemarau (Sudir \& Sutaryo, 2011).

Tabel 2. Ketahanan Varietas Padi Hibrida terhadap Penyakit BLB, di Sonopakis, Kasihan, Bantul, Yogyakarta, MK2015.

\begin{tabular}{clc}
\hline No & \multicolumn{1}{c}{$\begin{array}{c}\text { Varietas Padi } \\
\text { Hibrida/Pembanding }\end{array}$} & $\begin{array}{c}\text { Ketahanan Terhadap } \\
\text { Penyakit (BLB) } *\end{array}$ \\
\hline 1 & Hipa 8 & 3 \\
2 & Hipa 9 & 5 \\
3 & Hipa Jatim 2 & 5 \\
4 & Hipa 18 & 5 \\
5 & Hipa 19 & 5 \\
6 & Ciherang & 7 \\
7 & IR64 & 5 \\
\hline Keterangan: $*$ Skor berdasarkan standard evaluation system for rice $($ SES) \\
\\
& IRRI,1996; 1 = sangat tahan, 3= tahan, 5 = agak tahan, 7 = peka,9 \\
& $=$ sangat peka, BLB = Bacterial Leaf Blight = hawar daun bakteri \\
& (HDB).
\end{tabular}

\subsection{Jumlah Gabah Isi, Jumlah Gabah Hampa, dan Jumlah Gabah Total} per Malai

Tabel 3. memperlihatkan bahwa jumlah gabah isi per malai paling banyak diberikan oleh Hipa 8 (188 butir), sedangkan paling sedikit (168 butir) diberikan oleh Hipa Jatim 2 dan IR64. Jumlah gabah isi yang cukup banyak tersebut merupakan salah satu faktor penentu tingginya hasil yang diperoleh (Sutaryo, 2012)

Tabel 3. Rata-Rata Jumlah Gabah Isi per Malai, Jumlah Gabah Hampa per Malai, Jumlah Gabah Total per Malai, dan Hasil Gabah Kering Panen Varietas Padi Hibrida di Sonopakis, Kasihan, Bantul, Yogyakarta, MK 2015.

\begin{tabular}{lcccc}
\hline $\begin{array}{c}\text { Varietas Padi } \\
\text { Hibrida / } \\
\text { Pembanding }\end{array}$ & $\begin{array}{c}\text { Jumlah } \\
\text { Gabah Isi } \\
\text { per Malai (butir) }\end{array}$ & $\begin{array}{c}\text { Jumlah Gabah } \\
\text { Hampa per } \\
\text { Malai (butir) }\end{array}$ & $\begin{array}{c}\text { Jumlah Gabah } \\
\text { Total per } \\
\text { Malai (butir) }\end{array}$ & $\begin{array}{c}\text { Hasil } \\
\text { Gabah (t/ha } \\
\text { GKP) }\end{array}$ \\
\hline Hipa 8 & $190^{*}$ & $12^{\mathrm{ns}}$ & $202^{*}$ & $7,9^{*}$ \\
Hipa 9 & $177^{\mathrm{ns}}$ & $16^{\mathrm{ns}}$ & $193^{\mathrm{ns}}$ & $6,6^{\mathrm{ns}}$ \\
Hipa Jatim 2 & $168^{\mathrm{ns}}$ & $18^{\mathrm{ns}}$ & $186^{\mathrm{ns}}$ & $6,5^{\mathrm{ns}}$ \\
Hipa 18 & $175^{\mathrm{ns}}$ & $17^{\mathrm{ns}}$ & $192^{\mathrm{ns}}$ & $7,0^{\mathrm{ns}}$ \\
Hipa 19 & $187^{*}$ & $13^{\mathrm{ns}}$ & $200^{*}$ & $7,5^{*}$ \\
Ciherang & 173 & 18 & 191 & 6,3 \\
IR64 & 168 & 18 & 186 & 6,1 \\
\hline
\end{tabular}

Keterangan: * dan ns masing-masing adalah beda nyata dan tidak beda nyata terhadap Ciherang sebagai varietas pembanding terbaik pada uji t pada tingkat $5 \%$.
Selain memiliki gabah isi per malai tertinggi, Hipa 8 ternyata mempunyai jumlah gabah hampa per malai paling sedikit (Tabel 3.). Dalam hal jumlah gabah hampa ini seluruh VUB yang dikaji ternyata tidak berbeda dibanding dengan varietas pembanding terbaik (Ciherang).

Pada Tabel 3. terlihat bahwa jumlah gabah total per malai tertinggi dihasilkan oleh Hipa 8 yaitu 202 butir, sedangkan yang terendah dihasilkan oleh Hipa Jatim 2 dan IR64 yaitu 186 butir. Dari data jumlah gabah hampa dan dengan mempertimbangkan jumlah gabah total dari varietas padi yang diuji, maka hasil gabah dari varietas padi tersebut masih bisa ditingkatkan lagi, dengan lebih mengoptimalkan takaran dan cara pemupukan yang lebih tepat (Rustiati \& Abdulrachman, 2011). Hasil gabah juga masih dapat ditingkatkan dengan mengoptimalkan tanam jajar legowo-nya, karena kondisi pencahayaan matahari dan radiasi surya yang optimal dapat meningkatkan produktivitas padi (Hermanto, 2007).

\subsection{Hasil Gabah}

Pada Tabel 3. dapat dilihat bahwa hasil gabah VUB tertinggi di Sonopakis, Kasihan, Bantul, Yogyakarta diberikan oleh Hipa 8 yaitu 7,9 t/ha GKP diikuti oleh Hipa 19 (7,5 t/ha GKP), Hipa 18 (7,0 t/ha GKP), Hipa 9 (6,6 t/ha GKP), dan Hipa Jatim 2 (6,5 t/ha GKP), sementara Ciherang dan IR64 menghasilkan 6,3 dan 6,1 t/ha GKP. Walaupun Hipa 18, Hipa 9 dan Hipa Jatim 2 memberikan hasil berturut-turut 0,$7 ; 0,3$ dan 0,2 ton lebih tinggi dari Ciherang, namun hasil tersebut tidak berbeda nyata. Sedangkan Hipa 8 dan Hipa 19 dengan hasil berturut-turut 1,6 dan 1,2 ton secara nyata lebih tinggi di atas Ciherang. Bila dilihat dari asalusul tetua, tiga padi hibrida tersebut ini merupakan hasil persilangan yang salah satu tetuanya adalah pemulih kesuburan asal Indonesia yang memiliki daya adaptabilitas tinggi. Dengan demikian keragaan tiga padi hibrida tersebut memiliki keunggulan antara lain dalam hal umur tanaman, tinggi tanaman, jumlah anakan produktif, kebernasannya, kepulenannya, dan Hipa 8 memiliki ketahanan yang lebih baik terhadap penyakit kresek (HDB= hawar daun bakteri).

Secara keseluruhan, hasil yang diperoleh dari kajian varietas padi hibrida melalui pengelolaan tanaman terpadu ini lebih tinggi bila dibandingkan dengan hasil yang tertera dari deskripsi varietas unggul baru padi (Badan Litbang Pertanian, 2013). Kenyataan ini mengindikasikan bahwa peran dan kontribusi pengelolaan tanaman terpadu secara significan mampu meningkatkan hasil gabah.

\section{Simpulan}

Keragaan hasil gabah dan karakter agronomis padi hibrida di lahan sawah berpengairan teknis Sonopakis, Kasihan, Bantul, Yogyakarta terbukti mampu mendorong peningkatan produktivitas usahatani varietas padi hibrida Hipa 8 dan Hipa 19. Varietas Hibrida yang memiliki kelayakan secara berturut-turut mulai paling tinggi sampai terendah adalah Hipa 8, Hipa 19, Hipa 18, Hipa 9, dan Hipa Jatim 2. Penerapan budidaya PTT pada varietas padi hibrida dapat diandalkan untuk menstabilkan ketahanan pangan khususnya padi di Yogyakarta.

\section{Pustaka}

Anonim. 2014. Peningkatan produksi padi nasional. Online (Diakses 26 September 2014)

Badan Penelitian dan Pengembangan Pertanian. 2007. Petunjuk teknis lapang. Pengelolaan tanaman terpadu (PTT) padi sawah irigasi. Jakarta: Badan Penelitian dan Pengembangan.

Badan Penelitian dan Pengembangan Pertanian, Kementerian Pertanian. 2013. Deskripsi Varietas Unggul Baru Padi Inbrida padi irigasi (Inpari), inbrida padi gogo (Inpago), Inbrida padi rawa (Inpara), dan hibrida padi (Hipa).

Balai Pengkajian Teknologi Pertanian Yogyakarta. 2011. Laporan Akhir Pendampingan Program Sekolah Lapang Pengelolaan Tanaman Terpadu (SL-PTT) Display Padi Varietas Unggul Baru (VUB). BBP2TP-Badan Litbang Pertanian. Kementerian Pertanian.

Darsana, P. 2002. Agribisnis padi hibrida dan penyediaan benihnya. Seminar Padi Hibrida: Padi hibrida suatu peluang untuk meningkatkan ketahanan pangan dan agribisnis. Kerjasama Fakultas Pertanian UGM dengan Balai Pengawasan dan Sertifikasi Benih Daerah Istimewa Yogyakarta.

Dinas Pertanian Daerah Istimewa Yogyakarta. 2012. Road Map Swasembada Berkelanjutan 2010-2014. Yogyakarta: Dinas Pertanian DIY

Gomez, K.A., dan A.A. Gomez. 1995. Prosedur statistik untuk penelitian pertanian. Edisi Kedua. Jakarta: Universitas Indonesia (UI-Press).

Hasanuddin, A. 2004. Pengelolaan tanaman padi terpadu; suatu strategi pendekatan teknologi spesifik lokasi. Makalah disampaikan pada Pelatihan Pengembangan Varietas Unggul Tipe Baru (VUTB) Fatmawati dan VUB Lainnya 31 Maret-3April 2004, di Balitpa, Sukamandi.

Hermanto. 2007. PTT andalan peningkatan produksi padi nasional. Warta Penelitian dan Pengembangan Pertanian Indonesia. 26 (2): 14-15.

IRRI. 1996. Standard evaluation systemfor rice (3rd ed.). IRRI. Los Banos Philippines.

Pikukuh, B., S. Roesmarkam, dan S.Z. Saadah. 2008. Pengenalan varietas unggul baru di Jawa Timur untuk Mendukung Peningkatan Produksi Beras Nasional (P2BN). Prosiding Seminar Apresiasi Hasil Penelitian Padi Menunjang P2BN. Buku 1. Balai Besar Penelitian Tanaman Padi. Badan Penelitian dan Pengembangan Pertanian. 2008.

Rustiati, T., dan S. Abdulrachman. 2011. Komparatif beberapa metode penetapan kebutuhan pupuk pada tanaman padi. Prosiding Seminar Ilmiah 
Hasil Penelitian Padi Nasional 2010. Buku 2. Balai Besar Penelitian Tanaman Padi. Badan Penelitian dan Pengembangan Pertanian.

Satoto, A. Gani, S.T. Utomo, P. Sasmita, D. Setiobudi, T.S. Kadir, A. Guswara, P. Wibowo, E. Suhartatik dan A. Ruskandar. 2010. Pedoman Pelaksanaan Sekolah Lapang Pengelolaan Tanaman Terpadu (PTT) Padi Hibrida. Badan Penelitian dan Pengembangan Pertanian.

Sembiring, H. 2008. Kebijakan penelitian dan rangkuman hasil penelitian BB Padi dalam mendukung peningkatan produksi beras nasional. Prosiding seminar apresiasi hasil penelitian padi menunjang P2BN. Balai Besar Penelitian Tanaman Padi Sukamandi.

Simarmata, T. 2006. Teknologi peningkatan produksi padi (TPPP ABG) berbasis organik. Jakarta: PT. Gateway Internusa.

Sudir dan Suparyono. 2000. Evaluasi bakteri antagonis sebagai agensia pengendali hayati penyakit hawar pelepah dan busuk batang padi. Jurnal Penelitian Pertanian Tanaman Pangan. 19(2): 1-6.

Sudir dan B. Sutaryo. 2011. Reaksi Padi Hibrida Terhadap Hawar Daun Bakteri. Jurnal Penelitian Pertanian Tanaman Pangan. Pusat Penelitian dan Pengembangan Tanaman Pangan. Badan Penelitian dan Pengembangan Pertanian. 30(2): 88-94.

Suprihatno B, Darajat A, Satoto, Baehaki, Widiarta, Setyono A, Indrasari S, Lesmana O dan Sembiring H. 2009. Deskripsi Varietas Varietas Padi. Balai Besar penelitian Tanaman Padi, Badan Penelitian dan Pengembangan pertanian.

Sutaryo, B., dan Tri Sudaryono. 2012. Tanggap Sejumlah Genotipe Padi Terhadap Tiga Tingkat Kepadatan Tanaman. Jurnal Ilmiah Pertanian AGROS. Yogyakarta: Fakultas Pertanian Universitas Janabadra.

Sutaryo, B. 2012. Ekspresi daya hasil dan beberapa karakter agronomi enam padi hibrida indica di lahan sawah berpengairan teknis. Ilmu Pertanian (Agricultural Science). Jurusan Budidaya Pertanian Fakultas Pertanian Universitas Gadjah Mada. 12(2): 1-18. 